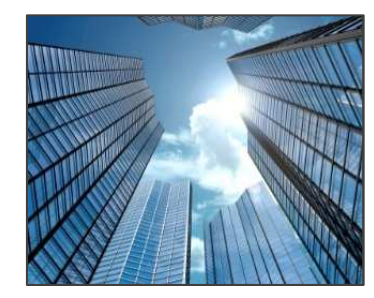

\title{
Understanding Institutional Change from a Gender Perspective
}

\author{
Working Papers in Gender and Institutional Change, No. 1 \\ December 2014
}

Georgina Waylen

Professor of Politics, University of Manchester

georgina.waylen@manchester.ac.uk

Published by the ERC funded project: 'Understanding Institutional Change: A gender perspective' 


\section{Abstract}

Many institutionalist scholars, and historical institutionalists in particular, have recognised for some time that our understanding of institutional change needs to be improved. Taking this premise as its starting point, this working paper develops it by arguing that we not only need to understand institutional change better but that we also need to improve our understanding of how it is gendered. The paper brings together key elements from institutional analysis with recent gender and politics scholarship, to form an analytical framework that can be used to examine how different instances of institutional change are gendered. After exploring the gaps in current analyses, the paper outlines some key insights from historical institutionalism (and particularly from Mahoney and Thelen's 2010 framework) as well as feminist institutionalism, delineating some different forms of institutional change and developing some key themes for each one that might enable us to better understand not only how each is gendered, but also how far each form might be used by change actors as a gender equity strategy. The working paper ends with a plea for further research to discern the utility of these concepts and framework.

\section{Keywords}

feminist institutionalism, gender, institutional change, institutions

\section{Acknowledgements}

Earlier versions of this paper were delivered at the European Conference on Politics and Gender (ECPG) held in Barcelona in March 2013 and at a PSA sponsored panel at the American Political Science Association (APSA) Annual Meeting held in Chicago in August 2013. I would like to thank all the participants and particularly the discussants for their interesting and insightful comments.

\section{Funders}

This research received funding from the European Research Council under the European Union's Seventh Framework Programme (FP/2007-2013) / ERC Grant Agreement n. 295576. 


\section{Introduction}

Many institutional scholars, and historical institutionalists in particular, have recognised for some time that our understanding of institutional change needs to be improved (Mahoney and Thelen 2010). This working paper takes this premise as its starting point and develops it by arguing that we not only need to understand institutional change better but that we also need to improve our understanding of how that change is gendered. In addition to adding a hitherto missing dimension to institutional analyses, this would also make an important contribution not only to gender and politics scholarship more generally but also to the emerging area of Feminist Institutionalism (FI) in particular. As changing institutions is a key priority for anyone wanting to promote gender equality, it would enhance our understanding of how institutional change, and the often-associated processes of institutional design, can be made more gender friendly - a question that has long preoccupied both feminist scholars and activists.

At the moment, despite the birth of a feminist institutionalism, neither the gender and politics nor the institutionalist scholarship on their own give us adequate tools to understand the gender dynamics of institutional change, and gaps remain in gendered analysis of institutions. Since the 1980 s New institutionalism in all its varieties - rational choice ( $\mathrm{RCI}$ ), sociological (SI), historical (HI) and more recently discursive institutionalism (DI) - has dominated recent approaches used to understand institutions (now generally understood to be rules, norms and practices) in many social science disciplines (Hall and Taylor 1996, Schmidt 2008). New institutionalism rekindled a concern for institutions that had dwindled after the behavioural revolution displaced the 'old institutionalism' with its emphasis on formal institutional structures. Recently interest in improving our understanding of institutional creation, continuity and change has increased - but how institutional change occurs is still weakly understood and the mechanisms of change are still disputed, even within the different strands of new institutionalism, let alone between them (Clemens 1999, Campbell 2010).

Despite this proliferation in institutional analysis, one area that all variants of new institutionalism has not addressed is how institutions and institutional change is gendered, even though the importance of gender has been recognized in many other sub-fields of social science. And although they now pay more attention to the effects of informal rules and norms, mainstream institutional scholars have largely neglected the gendered dimensions of institutional dynamics. As a result, most new institutionalist research is still gender blind. It rarely considers issues of gender and even if it does, fails to use a constructionist understanding of gender as reflecting multiple constitutive social processes and intersecting dynamics of power and 
difference that include dimensions such as class, race and sexuality (Scott 1986, Crenshaw 1991, Hawkesworth 1997, Connell 2002, Mohanty 2003).

This working paper brings together some key elements from institutional analysis (and in particular from the work on institutional change of HI scholars, James Mahoney, Wolfgang Streeck and Kathleen Thelen) and from recent gender and politics scholarship, to develop an analytical framework that can be used to examine different instances of institutional change. To demonstrate the importance of improving our understanding of how institutional change and the different processes associated with institutional change are gendered, the paper starts by examining the development of gendered analyses of institutions. It then looks at institutional analyses more generally, highlighting some of the gaps and deficiencies that remain. The second half of the paper outlines some preliminary ways in which new research might be undertaken. Exploring how one set of ideas emerging from $\mathrm{HI}$ could be used by feminist institutionalism, it delineates some different forms of institutional change and outlines some key themes for each one that will enhance our understanding of how each is gendered and how far each might be used by change actors as part of a gender equity strategy. 


\section{The State of the Art}

\section{Gender scholarship: understanding institutions and institutional change}

Increasingly categorized as constituting a feminist institutionalism (FI), a new body of scholarship that furthers our understanding of the gender dynamics of institutional change outside of gender-specific institutions has been emerging over the last few years (Mackay, Kenny and Chappell 2010; Krook and Mackay 2011). But inevitably it draws hugely on the existing gender and politics scholarship, even though most of this work has rarely seen itself as using institutionalist approaches. Indeed without this vast array of already existing gender scholarship, FI could not have developed. Gender and politics scholars have long demonstrated how gender is deeply implicated in institutions both nominally - through gender capture - and substantively - through mechanisms that result in gender bias that itself emerges from social norms based on accepted ideas about masculinity and femininity (Chappell and Waylen 2013). According to Chappell and Waylen (2013: 602) recognizing 'the institutional dominance of particular forms of masculinity has taken us from seeing gender operating only at an individual level, to viewing it as a regime'.

Although much of the early gender and politics work had looked primarily at the actions of women actors and women's movements in challenging gender inequality, it soon moved towards considering the interaction of different women actors with the wider political opportunity structure and a range of institutional structures (Celis, Kantola, Waylen and Weldon 2013). As a result gender scholars often incorporated formal institutions, as well as informal practices and norms, in their explanations of the interactions between social movements, political parties, and the state (for example Banaszak et al, 2003; Mazur, 2003; Lovenduski, 2005; Outshoorn and Kantola, 2007). Feminists exposed the gendered nature of public and political institutions and how they help to reflect, reinforce and constitute unequal and intersecting (gendered) power relations in wider society (Randall 1987, Acker 1992). Hugely important work was conducted on different formal institutions in four key state arenas: the bureaucratic; constitutional/legal; legislative and executive. For example it examined electoral institutions (such as First Past the Post and proportional representation systems), and welfare states (Ferguson 1984, Lovenduski and Norris, 1993, Orloff 2009). And recently the emphasis has also broadened ensuring that scholars undertake intersectional analyses, examining for example how gender intersects with other dimensions such class, race and sexuality (Collins and Chepp 2013).

The question of change - how change can be achieved and how institutions and policies can be made more gender friendly - has of course also been central to a feminist political science (FPS) 
as well as gender scholarship in other disciplines. Gender scholars and equity entrepreneurs have been involved in institutional (re) design, seeking to create gender-aware and more gender-just institutions: opening up institutions to wider inclusion and participation; seeking to insert new actors, rules, norms and practices; and attempting to recalibrate patterns of power (Mackay, Kenny and Chappell 2010). Gender scholars and entrepreneurs have, for example, investigated and advocated for state feminism and gender mainstreaming as well as policy interventions around issues such as domestic violence and reproductive rights (Stetson and Mazur 1995, Weldon 2002). However like institutionalist frameworks, the gender scholarship has often found understanding institutional creation, continuity and change problematic, particularly reconciling structure with agency. It has sometimes put too much emphasis on women's agency and not enough on the structural constraints that can have negative effects on outcomes. As a result understanding why institutional change, such as the establishment of women's policy agencies (WPAs), has not had the transformative effects that were hoped for, or has resulted in undesired and unpredicted unintended consequences, has been hard. Unlike some of the gendered welfare state, sociological and legal literatures, much gender and politics scholarship has also focused quite narrowly on explicitly gendered policy and institutional change - such as the implementation of equality policies, and the creation of WPAs. Less work has looked at wider institutional processes and how gender, intersecting with other dimensions of power such as race, class and sexuality, shapes those institutions. This focus on gender-specific institutions and a lack of a wider understanding of institutions and institutional change has sometimes limited its overall explanatory capacity. Therefore although this scholarship has many strengths, there are significant areas that need further development and expansion. Building on this work, it is the area of institutional change that this paper will now focus on.

\section{Institutional Analysis: recent developments in understanding institutions and change}

Even if it remains gender-blind, huge strides have also been made in the development of institutional analysis since scholars like March and Olsen (1984) pioneered the current debates. While there is some overlap between the four main variants of new institutionalism and some scholars have detected elements of convergence, significant methodological and theoretical differences remain, with important implications for the capacity of each to understand institutional creation, continuity and change - whether exogenous or endogenous, gradual or rapid. 
However there is now some consensus about what institutions are, how to define them and the centrality of rules and norms. Indeed Mahoney and Thelen (2010:4) claim that 'despite many other differences, nearly all definitions of institutions treat them as relatively enduring features of political and social life (rules, norms and procedures) that structure behaviour and cannot be changed easily or instantaneously'. This view fits with March and Olson's somewhat fuller definition of an institution as 'a relatively enduring collection of rules and organized practices, embedded in structures of meaning and resources that are relatively invariant in the face of turnover of individuals and relatively resilient to the idiosyncratic preferences and expectations of individuals and changing circumstances' (March and Olson 2006: 1).

Rules, norms and practices are therefore significant for all institutionalists, who make an important distinction between formally codified rules and more informally understood conventions and norms (Peters 1999). Exploring this distinction between formal and informal institutions and their interrelationship has become increasingly important in recent years (Helmke and Levitsky 2006; Azari and Smith 2012, Radnitz (2011). Helmke and Levistsky (2004: 727), pioneers in this field in comparative politics, define institutions as 'rules and procedures (both formal and informal) that structure social interaction by constraining and enabling actors' behaviour'. They see informal institutions as 'socially shared rules, usually unwritten, that are created communicated and enforced outside of officially sanctioned channels' in contradistinction to formal institutions which are 'rules and procedures, that are created communicated and enforced through channels widely accepted as official'. Others are now analysing the interaction between the two more systematically, emphasising for example the potential dynamism and adaptiveness of informal institutions as well as their potentially subversive or distorting roles and the possibilities for the creation of new ones (Tsai 2006, Grzymala-Busse 2010).

If we use this understanding of formal and informal rules, norms and practices, their role in change and conflict and the distribution of power as well as their role in maintaining stability and integration becomes centrally important. Any institutional change must mean changes to norms, rules and practices in all their forms. But because of differences in their approaches and frameworks, the main forms of NI understand change differently. Despite some useful analyses of the role of 'institutional work', Sociological Institutionalism (SI) finds it harder to contemplate change and changes to rules as occurring endogenously. It is most likely to be exogenous as a result of new interpretive frames or fields coming from outside. Sl's understanding of institutions and how they function can lead to a focus on cohesiveness, functionalism and stability - rather 
than being able to accommodate conflict and change. And for many Rational Choice Institutionalists ( $\mathrm{RCls}$ ), institutions are ultimately co-ordinating mechanisms that sustain or are moving towards particular equilibria, and so significant change must also be exogenous. In contrast Historical Institutionalism (HI) has a view of institutions, not as either cultural scripts or co-ordinating mechanisms, but as legacies of historical struggles (Mahoney and Thelen 2010). HIs use concepts like path dependence and critical junctures to help them understand the role of interests and their interaction with structures in the emergence and development of institutions. Institutions and their rules, norms and practices therefore shape power relations with distributional consequences, disproportionately distributing resources to actors already with power - it is these power-distributional implications of institutions that motivates change. But somewhat paradoxically $\mathrm{HI}$ until recently has been better at understanding continuity and stability, and exogenous rather endogenous, change.

However some $\mathrm{HI}$ scholars are now increasingly focusing on institutional - particularly endogenous - change and their work is particularly useful for the development of this research agenda (Streeck and Thelen 2005, Thelen 2009). They look at problems of compliance and enforcement - how and why actors obey or do not obey rules - as a fundamental source of change. Within $\mathrm{RCl}$ and $\mathrm{SI}$ frameworks compliance is not really an issue. But if institutions are seen as self-reinforcing and distributional issues are put at the centre then compliance becomes an important variable (Mahoney and Thelen 2010). Challenges and changes to rules, norms and practices become a central focus of any analysis of change. But these challenges and changes can take a variety of forms. They can include the contestedness of the institutional rules themselves as well as how far there is openness in the interpretation and the implementation of those rules. There is sometimes a great deal of 'play' in the interpreted meaning of particular rules and sometimes high levels of discretion in both their interpretation and enforcement. Rules are therefore ambiguous and subject of political skirmishing as, for example, Sheingate (2010) argues. When circumstances change and new developments confound rules, rule creation or an extension of existing rules to change institutions can occur. HI scholars therefore outline the ways institutional change of an incremental endogenous variety can happen in 'gaps' and 'soft' spots between a rule and its interpretation and enforcement as well as more clear-cut and exogenous change (Thelen 2009). Although not framed in those terms, this $\mathrm{HI}$ approach has resonances with some of the recent work on informal rules, norms and practices even if some $\mathrm{HI}$ scholars have sometimes been somewhat dismissive of the need to include informal institutions in their analyses (Streeck and Thelen 2005: 10). 
In an important recent contribution systematising much of this earlier HI work, Mahoney and Thelen (2010) delineate four types of institutional change that evidence different forms of rule change and contestation. The first category is displacement. This involves the removal of old rules and the introduction of new ones. Although often abrupt and not inherently a gradual form of change, displacement can also be slow moving. Normally new institutions are created by actors - termed "insurrectionaries" by Mahoney and Thelen (2010) - who were "losers" under old system but now face weak veto possibilities as well as low levels of discretion in the enforcement and interpretation of rules. So displacement can involve a significant upheaval as old rules are swept away for example after a revolution, military defeat and some transitions to democracy.

The second type of change is layering in which new rules are introduced alongside or on top of existing ones. Layering often happens when institutional challengers lack the capacity to alter the existing rules as veto players can protect existing institutions and there is limited discretion in the enforcement and interpretation of the old rules. These 'subversives' can disguise the extent of their desire for change by appearing to work within the system. But the new institutions can often have a significant impact on the existing ones that they are alongside or on top off. Recent changes in UK education policy promoted by the Coalition government and its education minister Michael Gove such as the promotion of academy and free schools alongside existing state funded schools could be seen in this way. The third form is drift - the effects of existing rules change because of shifts in the environment. If key actors choose not to respond to those shifts then their lack of response can result in a change to that institution. The change is therefore a result of a failure to adapt and update an institution so that it can maintain the same impact in an altered context. Drift often occurs when veto players have sufficient power to prevent the outright displacement of an institution but there is often a gap (for example due to neglect) between the rules and their enforcement that facilitates change. Conversion is the final form of change. Existing rules are strategically redeployed as actors actively exploit the inherent ambiguities of institutions. Conversion typically occurs in contexts where change actors (often labelled "opportunists" by Mahoney and Thelen) lack the capacity to destroy an institution but are able to exploit gaps and spaces in the interpretation and implementation of existing rules to redeploy them in ways not anticipated by their designers. As a result the institution is converted to new goals, functions or purposes.

Mahoney and Thelen's typology highlights the varying roles and power of a range of actors both change agents and veto players - in different forms of change. It offers a potentially 
important framework that can inform efforts to understand institutional creation, continuity and change both in theoretical and empirical terms. Therefore despite not incorporating gender into its frameworks and its failure to explain or understand how institutional change is profoundly gendered, the potential for a synthesis does exist. It is this framework elaborated by Mahoney and Thelen's that we will take forward to inform our analysis. But first it is useful to consider how FI has used institutional analysis to date.

\section{Towards a Synthesis?}

As an initial step towards synthesising these separate, but potentially complementary, bodies of scholarship, some recent feminist institutionalist scholarship has explored the potential of institutional approaches for gendered analyses. New FI work has considered how we can analyse rules as gendered in ways influenced by institutionalism (Lowndes and Roberts 2013). Others are beginning to look at informal institutions - long recognised by gender scholars as significant in gender terms - drawing on the recent literature that explores systematically how the formal and informal can interact together both to subvert and uphold each other with varying gender outcomes (Mackay 2010, Chappell and Waylen 2013, Chappell 2014, Waylen 2014). Fl has explored the possibilities for each of the main approaches associated with institutionalism $(\mathrm{RCl}$, $\mathrm{HI}, \mathrm{SI}$ and $\mathrm{DI}$ ) to incorporate gender into its analyses. Thus far it appears that, in comparison to $\mathrm{RCl}$, with its emphasis on non-gendered individuals as rational utility maximisers, $\mathrm{HI}$ (and to some extent SI and $\mathrm{DI}$ ) as relatively methodologically pluralist, problem driven and historically focused has more potential to incorporate gender into its frameworks as well as offering some appropriate tools that can be utilized by gender and politics scholars (see Critical Perspectives, Politics and Gender, June 2009). Much recent constructionist theoretical work on gender shares with $\mathrm{HI}$ an emphasis on context dependence and the necessary historicity of concepts and analysis. As we have seen, $\mathrm{HI}$ also focuses on power struggles and distributional questions, even if gender does not usually figure as part of this. And there is some evidence that, for example in Theda Skocpol's (1992) work on the development of the American social policy, and in Paul Pierson's (1996) work on European integration that examines gender equality in the European Community, this interaction can sometimes occur.

Some gender and politics scholars have also utilized NI and particularly $\mathrm{HI}$ to improve their analyses of large-scale cases of institutional creation, continuity and change (or have been identified as doing so by others) (Waylen 2009, Htun 2003. O'Connor, Orloff, and Shaver 1999). While not appropriate for every research question, this work demonstrates the potentially 
significant contribution of $\mathrm{HI}$ approaches in improving the answers to some big questions that have preoccupied gender scholars: such as how certain institutions and regimes are gendered, how they came into being, and how change can occur, as well as understanding the relationship between different actors and the institutional context (Waylen 2009). This in turn can help us to understand how positive gender change - leading to improvements in women's descriptive and substantive representation - can come about. $\mathrm{HI}$ approaches can therefore be useful for gender scholars in explaining how particular institutions and regimes arose, how they are gendered and why it is often so difficult to change them, But FI also has to consider how these approaches might help in improving our understanding of how and why certain institutions can or cannot be renegotiated, focusing both on the formal and informal variants and the ways in which institutions have gendered rules, norms, practices and logics (Chappell 2006). And through early concepts like critical junctures, feedback mechanisms, and especially more recent ones such as institutional conversion and layering, $\mathrm{HI}$ offers tools that can help to capture the dynamics of continuity and change in gender and politics. As a result it should also be easier to structure gender and politics scholarship findings in ways that better highlight the contributions that gender research makes to both mainstream political science research and to broader understandings about the complex relationships between structure and agency in political life. The emergence of feminist institutionalism therefore offers an opportunity to improve the explanatory capacity of both feminist political science and institutional analysis.

In order to advance our understanding of the gender dynamics of institutional change particularly more gradual endogenous change, we need to draw on both this latest institutionally focused gender research and the new HI scholarship to undertake meso level and contextually specific analyses. For different forms of change, these analyses should investigate both formal and informal rules, norms and practices and the ways in which these rules, norms and practices shape power relations with distributional consequences. Challenges to and the creation and adaption of rules, norms and practices therefore become a central focus in any attempt to understand gendered institutional change. 


\section{The Way Forward}

As understanding how institutional change is gendered is such a huge area of investigation, the second half of this working paper will bring together and operationalize some of these ideas in order to convert them into manageable research areas. As we have seen, two major tasks relevant to our purposes stand out from the institutionalist literature. The first is that gender scholars need to focus on institutions as rules, norms and practices in both their formal and informal guises (Chappell and Waylen 2013). Any form of institutional change is going to involve both the formal and informal interacting together in ways that need to be investigated. The role of informal institutions as a key dimension in their own right has, until recently, not had sufficient attention from those looking at institutional change. But as we have seen, non gender scholars interested in understanding institutions have focused much more centrally on informal institutions in the last decade. However although gender scholars have recognized how gendered norms, practices and discourses can constitute as well as undermine formal institutions (such as candidate selection procedures and bureaucracies) and embody masculinities (and femininities) in particular ways this has only recently started to be done within an institutionalist framework (Connell 2002, Bjarnegard 2013, Kenny 2013). Feminist institutionalist scholars have begun to look more explicitly at the "hidden life of institutions and in particular at the relationship between formal and informal institutions, using some of the ideas put forward by other non gender institutionalist scholars to ask how they might interact together (Chappell and Waylen 2013, Chappell 2014). Interrogating not only how existing informal rules about gender (such norms about appropriate dress and behaviour) might undermine sometimes progressive formal rule change, this work has also examined how informal rule change might complete and coordinate and even initiate formal rule change in ways that feminists might not expect (Waylen 2014). In many countries for example, the introduction of civil partnerships and gay marriage has followed changed informal rules about homosexual relationships. Causality can therefore run both ways and any gender actors wishing to introduce gender positive institutional change need to consider how to change informal as well as formal rules.' Improving our understanding of the informal and its relationship to the formal therefore remains a big challenge.

The second theme to emerge from the previous discussion is that as institutional change is extremely complex and can take many different forms - gradual and endogenous as well as rapid and exogenous - it is useful to separate out these different forms. Cognizant of the dangers of over-rigidly sub-dividing what are messy and overlapping phenomena, we can use Mahoney and Thelen's (2010) typology as a heuristic device to develop contextually specific analyses that will 
allow us to pursue comparative analyses of different types of change - thus enabling us to examine both rapid, often exogenous, change such as displacement as well as more gradual endogenous forms like layering, conversion and drift. For each form we can analyse a range of factors such as: the change agents, the veto possibilities as well as the rules - their creation, interpretation and enforcement - in both their formal and informal guises.

For each form of change, it is also important distinguish two analytically separate areas of investigation (although in practice they can intersect). First we need to be aware that each form of institutional change is gendered and has gendered impacts and implications; and second there are also forms of institutional change that come about through deliberate processes of design aimed to promote gender equality. Therefore although all forms of change are gendered, not all forms are likely to be used by institutional designers as deliberate strategies to enhance gender equality, and some forms of change appear more likely to be adopted as gender equality strategies than others. In a number of cases where gender equality agents have achieved some modicum of institutional change, sufficient time has passed to allow us to consider the extent to which these different instances of institutional change have themselves been subject to displacement, drift, layering and conversion as opponents with varying amounts of power attempt to undermine them. These more nuanced analyses should enable to us to see under what circumstances some of kinds of change are more likely to be effectively utilized by gender equality entrepreneurs. We can now outline some brief analyses of how these different forms of change are gendered and offer some preliminary thoughts about to extent to which each might be a feasible gender equality strategy.

\section{Displacement}

Displacement, the wholesale replacement of old rules by new ones, happens relatively rarely. But it does contain the potential for significant institutional change, often occurring at a time of fundamental rupture - 'a critical juncture' - for example when 'usurpers', who were losers under old system, gain the power. Often the destruction or discrediting of the previous regime means that opponents' veto power is low, and, particularly in a context where there is little discretion in existing rules, the 'usurpers' use their newly gained powers to sweep away the old rules and replace them with new ones (this process can also be slow-moving as well as rapid). However even institutions created in this way can often face 'nested newness' as the impact of preexisting rules, norms and practices remains significant (Mackay 2009). 
These processes and their outcomes are gendered, both implicitly or explicitly, in ways which vary according to a range of contextual factors. Displacement can provide the space for significant change in the ways that institutions are gendered in range of forms that feminists may deem to be either progressive or retrogressive. And although displacement is unlikely to be a widely used gender equality strategy in isolation from broader institutional change as gender actors are unlikely to have sufficient power in combination with the absence of a significant veto, there are examples where gender equality policies have formed part of broader institutional changes.

Among the recent examples of institutional change that might be deemed retrogressive in gender terms are those associated with Islamic fundamentalist regimes like the one that took power after the Iranian Revolution in 1979 and rule of the Taliban rule Afghanistan from 1996 until they were was forcibly deposed at the end of 2001 (Kandiyoti 2005, Moghadam 1999). Both regimes imposed their version of sharia law with rules and practices that embody a particular gender regime with very explicit rules about gender for example around appropriate male and female dress - such as male facial hair, and veiling for women, as well as rules around employment, education, mobility, travel, and political rights with very different implications for men and women. The rules and norms enforce certain versions of masculinity and femininity as well as very different roles within public and private spheres for men and women. European fascist regimes, epitomised for example by Nazi Germany in the 1930s, provide another example of the imposition of institutions based on an extremely conservative vision of gender relations (Koonz 1987).i Under both these Islamic and fascist states, progressive gender actors had little power to influence rule-making or to subvert the processes of rule implementation (although the degree to which this could happen did vary). The degree to which institutions were 'new' was also complex. Regimes referred back to 'tradition', history, religious law and convention as justification when establishing 'new' rules and procedures.

In other contexts gender actors have found space to be involved in other processes of rapid institutional change and some progressive gender changes - such as in some recent cases of post conflict constitution-making and transitions to democracy - have resulted. In South Africa, a transition to democracy was negotiated after years of struggle by the excluded non-white majority against the racially exclusionary apartheid regime. The National Party government was sufficiently weakened (or at least could see no possibility of defeating the opposition) and therefore felt it had no option but to negotiate. But it did retain some veto power (particularly on economic issues). The 'usurpers', the non white majority, took political (but not economic) 
power and was represented primarily by the African National Congress (ANC). Many of the rules that comprised the apartheid institutions were swept away (although there had already been some conversion and drift when, although extreme levels of state repression were maintained, a number of rules - relating for example to marriage and residence laws - were no longer enforced as rigidly as they had been .

For most of its history, the ANC had fought on a platform of rights, equality and justice for all in a multi-racial state. Feminists could frame their demands for gender equality in this way too. Women activists, organizing around gender issues, had been increasingly active within ANC and outside of it since the 1980s, and during the transition an important alliance of women of all races, formed into the Women's National Coalition (WNC), campaigned effectively to get gender equality enshrined within the new Constitution and Bill of Rights (Hassim 2005). But gender actors, despite some of their best efforts and considerable successes, also often faced 'nested newness'. New institutions are rarely created with a blank slate. 'Old' rules, norms and practices (both formal and informal) remain and even at times of great rupture, not all existing institutions can be swept away and pre-existing rules and norms are incorporated into the newly created institutions in new ways. For example as a result of the dispute between gender actors and traditional leaders over the status of customary law in the process of constitutional design, two new institutions - the Council for Gender Equality and the Council of Traditional Leaders - were created as part of a (immediate but only temporary) resolution to the issue in the new South Africa (Waylen 2007a).

Therefore, although not often a gender equality strategy on its own, under certain circumstances displacement can bring some gender progressive institutional change as part of broader changes, for example as part of a 'progressive' agenda that is enhancing citizen's rights and promoting equality more generally.

\section{Layering}

Layering - the introduction of new rules alongside or on top existing ones - is a relatively more common way to change institutions, allowing those actors who do not have sufficient power to sweep away old institutions to make some potentially far-reaching changes even in the face of some quite strong veto players. As a result new governance structures are often created to operate alongside or on top of existing ones with gendered effects. One example of layering worth exploring here because it is often cited in the institutionalist literature but without fully 
considering the gender dimension, is the introduction of new pensions arrangements (Hacker 2005). As part of efforts to move the balance of pensions systems from state organised defined benefits pay-as-you-go to private sector dominated defined contributions pensions, new private sector pensions schemes have been widely introduced alongside existing pensions schemes (often with incentives and/or compulsion for workers to join them) often with the aim of 'crowding out' existing state-run pensions schemes (in contexts where their abolition would be politically impossible).

Although often ostensibly gender neutral, these new arrangements have distinctly gendered impacts, that can affect men and women very differently. This is due in large part to men and women's different positions in the labour market over their life cycles - women often undertake less paid work (for example because of time spent looking after dependents, are more likely to work part-time work and have often had earlier retirement ages) and on average they earn lower wages than men - which means that they generally contribute less to pension schemes (Steinhilber 2004). Despite being based on a male bread-winner model, state-run definedbenefits systems are often relatively more favourable to women, frequently offering standard benefits or entitlements according to need. The move towards more market-based capitalized systems based on equivalence (benefits are a function of what has been paid in) and an assessment of risk (such as projected survival rates) often result in women receiving substantially lower pensions on average than men (if they are entitled to them at all) and lower pensions even than men earning the same salary as themselves (Waylen 2007b). And auto-enrolment, one of the latest changes to pensions institutions based on a 'nudge' (Thaler and Sunstein 2008) in which, unless individuals opt-out, they will automatically be members of a pension scheme, also appears likely to have gendered impacts which have not been fully considered by policymakers. More women, because of their lower earnings and higher levels of part-time work, remain less likely to meet the income threshold at which auto-enrolment takes place and therefore will still receive lower pensions than men. But until the relatively recent panic about the potentially high levels of female pensioner poverty, few academic analyses of pensions considered how pension reform is gendered, and even now, few studies have done this within an institutionalist framework (Staab 2014).i.i

Layering has also been quite widely used as a gender change strategy. Gender change actors are frequently in situations in which, even if they do have some capacity to introduce new rules, their power is limited. Quotas in the electoral arena, and gender mainstreaming and women's policy agencies (WPAs) in the bureaucratic arena are some of the best known examples of new 
institutions designed to promote gender equality layered on to existing institutions (Krook 2006). A number of factors affect the success of these new institutions. Among them are: the effectiveness of their design - sometimes looseness or ambiguity in the rules allows them to be implemented in ways not intended by their designers, enabling political parties for example to evade quota laws. Second the extent to which the new rules impact on the existing institutions that they are on top of or alongside affects their success. In some cases the impact of quotas has been increased through diffusion or contagion as other parties fear losing votes or appearing oldfashioned. And finally the extent to which pre-existing informal rules and norms impact on effective implementation; or indeed whether the emergence of new informal norms - such as a growing unacceptability of low levels of women's representation - leads to the more stringent enforcement of formal rules to complete those institutions and enhance their success.

\section{Drift}

Drift is a slow moving form of change in which the existing rules do not change but their impact does because of shifts in the external environment (perhaps in combination with gaps in and neglect of the formal rules), thereby giving institutions new meaning. Changes to the US welfare system are often cited as the classic example of policy drift, as formal rules around welfare were maintained as the same time as society changed, undermining those formal rules as they became increasingly out of step with wider changes (Hacker 2005). Drift also has important gendered impacts. The male bread winner model underlying many welfare states, not just in the USA, eroded - in part as a consequence of the large increases in female employment which was combined in many contexts with increased numbers of single parent (predominantly femaleheaded) households. However many formal rules based on this model remained in place, resulting in contradictory gender outcomes (Esping-Andersen 2009). Institutionalist scholars like Hacker (2005) have recognized how changes to the external environment, such as increasing rates of divorce and labour market changes, were highly gendered, but do not consider how the institutions themselves are gendered as our earlier example of pensions systems demonstrated and that these institutions also contribute to gendered outcomes such as female pensioner poverty.

Drift, in part because of its relatively long time horizon and unpredictability, is unlikely to be a frequently adopted gender equality strategy except perhaps in contexts where the non enforcement of existing gender unequal rules (for example forbidding women from undertaking certain activities) is the only strategy available to equality actors who do not have to power to 
change rules. Policy drift can also be used by those opposing gender equality strategies - for example allowing institutions like WPAs to 'wither on the vine' by not appointing staff or increasing their budgets in line with other state institutions - thereby rendering them powerless through neglect and marginalization in contexts where their abolition is impossible.

\section{Conversion}

Conversion as a form of institutional change can take place in contexts where the capacity to create new institutions is limited (for example due to the strong veto power of vested interests) but where there is also sufficient slack and ambiguity within existing rules to enable actors to redirect an institution to play a different role. Again this redirection of existing institutions will have gendered impacts which may be positive or negative; and conversion can also be used as gender equality strategy in contexts where gender equality actors do not have the power to create new institutions. If we return to the South African transition to democracy, in addition to the creation of new institutions such as the constitution and a new electoral system, efforts to redirect some already existing institutions were made, redeploying old rules in new ways not intended by their original creators. After 1994, the South African parliament continued to sit in the pre-existing Cape Town legislature after it was deemed to be too expensive to build a new one and many existing rules and practices were kept (Waylen 2011). But the institutional symbol of white domination under apartheid was also to be changed from a racially exclusive parliament into a 'people's parliament' representing all the population that embodied the 'new nation'. So many of the rules and practices that had been imported from the Westminster parliament (on which it had originally been modelled) such as the Mace, Black Rod, Whips and a Speaker, remained. But they were redesigned and re-imagined to represent this new South Africa (incorporating new symbols such as an African drum) (Waylen 2011). The first Speaker in the new parliament was an Indian woman, a renowned feminist and longstanding ANC activist who wore a sari while presiding over sittings, providing a very visible symbol of the transformation that parliament had undergone.

Indeed one of the biggest changes was the transformation in the composition of the MPs brought by the transition to democracy, leading Marc Howard Ross (2009) to claim that it was this influx that made a huge contribution to the appropriation of the institution. Not only were there now large numbers of black African MPs who had never had a presence there before (there had been some Indian and coloured members in their own powerless assemblies in later years of apartheid), but the 1994 elections also brought substantial numbers of women into parliament. Virtually no women had been elected under Apartheid) (Geisler 2000). An ANC party quota of 33\% 
(which also led to some contagion in other parties) was primarily responsible for a parliament comprised of $27 \%$ women. Parliament was therefore also very different in terms of dress (madiba shirts as well as business suits were now acceptable) and language (there were now 11 Official languages - not just English and Afrikaans); but also in terms of the facilities that were needed (for example there were not enough women's toilets). The parliament was also to be more open to the public - women's and youth parliaments were to be held in the chambers when parliament was in recess. The new women MPs - many of whom had been in the WNC and had worked together during the transition - acted together to ensure that gender legislation was passed for example in the areas of reproductive rights, gender violence in the parliament's first term (Waylen 2007b). But many new women MPs - particularly those from activist and nonprofessional backgrounds - also found it an intimidating space despite the attempts to make it a 'people's parliament' and more accessible to all (Britton 2006). The maintenance of many of the complex old procedures and practices as well as staff from the apartheid era contributed to this. There was a high attrition rate of women MPs with large numbers leaving after one term. Therefore as part of the strategy of conversion of parliament to pursue new goals, a more gender equal institution emerged, but despite the efforts to transform the institution, significant elements of its previous incarnation remained.

There are also examples of the use of conversion as a deliberate gender equality strategy in contexts where gender equality actors do not have the power to create new institutions. Michele Bachelet, elected to the presidency in Chile in 2006 on a platform that included implementing positive gender change, attempted to interpret and enact existing rules in new gender positive ways in the face of significant structural constraints and a powerful conservative opposition, with some mixed results (Waylen 2014). Some new (limited) policies were introduced, for example around reproductive rights, while others such as electoral quotas failed. Conversely we have seen new, sometimes more conservative governments, redirect WPAs set up by previous administrations away from gender equality to prioritise family and child welfare in contexts (such as East/Central Europe) where the abolition of the institution is not thought possible (Waylen 2007b). 


\section{Conclusions}

This working paper has brought recent developments in feminist institutionalism together with institutionalist analyses (and in particular with the work of historical institutionalists Mahoney, Streeck and Thelen) to examine institutional change. It argues that synthesising these approaches can improve our understanding of institutions and processes - rapid or gradual, exogenous or endogenous - of institutional change and how they are gendered. In particular, identifying and disaggregating different forms of change can allow us to develop more nuanced analyses - ones that are alert to different contexts, the role of veto players and the varying opportunities available to different change actors. It can also show us that not just formal but also informal rules, norms and practices are an important dimension of institutional analysis. Different forms of change therefore can offer a range of outcomes. It now remains for feminist scholars to undertake more detailed empirical research to explore how far delineating different forms of change in this way does improve our understanding of the gendering of institutional change and whether the frameworks and concepts outlined here require further refinement and adaptation.

It is hoped that these insights and the findings of any subsequent research will also provide valuable lessons for institutional designers. The aim is to determine which strategies might be appropriate and possible in different contexts - depending on a range of factors such as the power and capabilities of both change actors and their opposing forces, as well as the strength of pre-existing rules in both their formal and informal guises. The foregoing analysis has demonstrated the need to ensure that institutions are effectively designed for the particular context they are created in, ensuring for example that where appropriate new rules have a degree of slack and ambiguity to ensure that attempts to derail them do not succeed. It is important to be mindful of the fragility of some new institutions like women's policy agencies, that can sometimes be relatively easily dismantled (displaced), marginalised and allowed to wither (drift), or else transformed (converted) to prioritise different goals - such as bolstering the family - to the ones their designers had had in mind.

There are many other dimensions of institutional change that still need further investigation. To date intersectional analyses have not had the prominence that they should. The move towards more general equalities policies (that encompass race, disability, sexuality etc as well as gender) is one instance of institutional layering that would be amenable to a more institutionally focused intersectional analysis. And finally the recent fate of some equalities policies and women's policy agencies at a time of austerity demonstrates that understanding institutional change must also 
encompass not only positive change, but also of how institutional retrenchment takes place. To help us with these endeavours, this working paper has outlined some building blocks for future researchers to use and to refine in order to enhance our understanding of the gendering of institutional change. 


\section{References}

Acker, J. (1992) 'From Sex Roles to Gendered Institutions'. Contemporary Sociology, 21(5) 565-69

Azari J. and Smith, J. (2012), 'Unwritten Rules: Informal Institutions in Established Democracies', Perspectives on Politics, 10, 1: 37-55.

Banaszak, L.A., Beckwith, K. and Rucht, D. (eds) (2003) Women's Movements facing the Reconfigured State. Cambridge: Cambridge University Press.

Bjarnegard, E. (2013) Gender, Informal Institutions and Political Recruitment, Basingstoke: Palgrave.

Britton, $\mathrm{H}$ (2006). Women in the South African Parliament: from resistance to governance. University of Illinois Press.

Campbell, J. (2010) 'Institutional Reproduction and Change', in G Morgan, J Campbell, C Crouch, OJ Pedersen and R Whiteley (eds) The Oxford Handbook of Comparative Institutional Analysis, Oxford University Press.

Celis, K, Kantola, J, Waylen, G and Weldon, L. (2013) 'Introduction: A gendered politics, a gendered world' in Waylen et al (eds) Oxford Handbook of Gender and Politics. Oxford: Oxford University Press.

Chappell, L. (2002) Gendering Government: Feminist Engagement with the State in Australia and Canada. Vancouver: University of British Columbia Press.

Chappell, L. (2006) 'Comparing Political Institutions: Revealing the Gendered "Logic of Appropriateness"', Politics \& Gender, 2 (2), 223-248.

Chappell, L. (2010) 'Comparing Institutions: A research Agenda', Perspectives on Politics, 8, 1.

Chappell, L. (2014) 'Conflicting Institutions and the search for gender justice at the International Criminal Court' Political Research Quarterly, 67, 1.

Chappell, L and Waylen, G. (2013), 'Gender and the Hidden Life of Institutions', Public Administration, 91, 3: 599-615.

Clemens, E. and Cook, J. (1999) 'Politics and Institutionalism: Explaining Durability and Change', Annual Review of Sociology,

Collins, P H and Chepp, V. (2013), 'Intersectionality' in Waylen et al (eds) Oxford Handbook of Gender and Politics. Oxford University Press.

Connell, R.W. (2002) Gender, Cambridge: Polity Press.

Crenshaw, K. (1991) 'Mapping the Margins: Intersectionality, Identity Politics and Violence against Women of Color', Stanford Law Review. 
Esping-Andersen, G. (2009) The Incomplete Revolution: Adapting Welfare States to Women's New Roles. Polity Press

Geisler, G. (2000), 'Parliament is Another Terrain of Struggle', Journal of Modern African Studies, 38, 4:606-19.

Grzymala-Busse, A. (2010), 'The Best Laid Plans: The Impact of Informal Rules on Formal Institutions in Transitional Regimes', Studies in Comparative International Development, 45, 3: 311-33.

Hacker, J. (2005) 'Policy Drift: The Hidden Politics of US welfare state retrenchment' in W Streeck and K Thelen (Eds), Beyond Continuity: Institutional Change in Advanced Political Economies, Oxford University Press.

Hall, P. and R. Taylor. (1996) 'Political Science and the Three New Institutionalisms', Political Studies, 46 (5), 951-957.

Hassim, S. (2006) Women's Organizations and Democracy in South Africa: Contesting Authority, Madison: University of Wisconsin University Press.

Hawkesworth, M. (1997) 'Confounding Gender', Signs, 22 (3).

Helmke, G. and S. Levitsky. (2004) 'Informal Institutions and Comparative Politics: A Research Agenda', Perspectives on Politics, 2 (4), 725-740.

Helmke, G and Levitsky, S. (2006), 'Introduction', in G Helmke and S Levistsky (eds), Informal Institutions and Democracy: Lessons from Latin America. Johns Hopkins University Press.

Htun, M. (2003) Sex and the State. Cambridge: Cambridge University Press.

Kandiyoti, D. (2005) The Politics of Gender and Reconstruction in Afghanistan, Occasional Paper no 4, Geneva: UNRISD.

Kenny, M. (2007) 'Gender, Institutions and Power: A Critical Review’, Politics, 27 (2), 91-100.

Kenny, M. (2013) Gender and Political Recruitment. Basingstoke: Palgrave.

Koonz, C. (1987) Mothers in the Fatherland: Women, the family and Nazi Politics. London: Routledge.

Krook, M.L. (2006) 'Beyond Supply and Demand: Gender Quotas and the Institutions of Candidate Selection', Paper presented at the First Workshop of the Feminism and Institutionalism International Network, Edinburgh, 8-9 December.

Krook, M.L. and F. Mackay. (2011) Gender, Politics, and Institutions: Toward a Feminist Institutionalism. Basingstoke: Palgrave. 
Lovenduski, J. (1998) 'Gendering Research in Political Science', Annual Review of Political Science, 1, 333-356.

Lovenduski, J. (ed) (2005) State Feminism and Political representation. Cambridge: Cambridge University Press.

Lowndes, V. (2002) 'Institutionalism" in D. Marsh and G. Stoker (eds) Theory and Methods in Political Science. Basingstoke: Palgrave. 90-108.

Lowndes, V, and Roberts, D. (2013) Why Institutions Matter, Palgrave.

Moghadam, V. (1999) 'Revolution, Religion and Gender Politics: Iran and Afghanistan Compared', Journal of Women's History, 10, 4: 172-95.

Mohanty, CT. (2003) Feminism Without Borders: Decolonizing Theory, Practising Solidarity. Duke University Press.

Mackay, F. (2004) 'Gender and Political Representation in the UK: The State of the "Discipline"', British Journal of Politics and International Relations, 6 (1), 99-120.

Mackay, F. (2009) 'Nested Newness', paper, ECPG conference, Belfast, January.

Mackay, F. and Meier, P. (2003) 'Institutions, Change and Gender Relations: Towards a Feminist New Institutionalism?'. Paper presented at the European Consortium for Political Research, Joint Sessions of Workshops, Edinburgh, 28 March - 2 April.

Mackay, F, Kenny, M and Chappell, L. (2010) New Institutionalism Through a Gender Lens: Towards a Feminist Institutionalism? International Political Science Review, 31, 5.

Mahoney, J. and K. Thelen. (eds) (2010) Explaining Institutional Change: Ambiguity, Agency, and Power. Cambridge University Press.

March, J.G. and J.P. Olsen. (1984) 'The New Institutionalism: Organizational Factors in Political Life', The American Political Science Review, 78 (2), 734-749.

March, J.G. and J.P. Olsen. (1989) Rediscovering Institutions: The Organizational Basis of Politics. New York: Free Press.

Mazur, A. (ed) (2001) State feminism, Women's Movements and Job Training. London: Routledge.

O'Connor, J, Orloff, AS, Shaver, S. (1999), States, Markets, Families: Gender, Liberalism and Social Policy in Australia, Canada, Great Britain and the United States, Cambridge.

Orloff, AS. (2009) 'Gendering the Comparative Analysis of Welfare States: An Unfinished Agenda', Sociological Theory, 27, 3.

Outshoorn, J. and Kantola, J. (eds) (2007) Changing State Feminism. Basingstoke: Palgrave.

Peters, B.G. (1999) Institutional Theory in Political Science: The New Institutionalism. London. 
Pierson, P. (1996) 'The path to European integration: a historical institutionalist approach', Comparative Political Studies, 29 (2), 123-63.

Radnitz, S. 2011. 'Informal Politics and the State'. Comparative Politics 43, 3: 351-71.

Ross, M H. (2009) 'Strategies for Transforming and Enlarging South Africa's Post Apartheid Symbolic Landscape' in Ross MH (ed) Culture and Belonging in Divided Societies: Contestation and Symbolic Landscapes. University of Philadelphia Press.

Schmidt, V. (2008) 'Discursive Institutionalism: The Explanatory Power of Ideas and Discourse', Annual Review of Political Science, 11, 303-26.

Scott, J. (1986), 'Gender: a useful category of historical analysis', American Historical Review, 91: $1053-75$.

Skocpol, T. (1992) Protecting Soldiers and Mothers: The Political Origins of Social Policy in the United States. Cambridge, MA: Harvard University Press.

Sheingate, A. (2010) in Mahoney and Thelen (eds) 'Understanding Rules Changes in the Senate' Explaining Institutional Change, Cambridge University Press.

Staab, S (2014) (En)gendering Change and Continuity in Chilean Social Policy: Actors, Ideas and Institutions, Unpublished PhD, University of Manchester.

Steinhilber, S. (2004), 'The Gender Impact of Pensions Reform: Case Studies of the Czech Republic, Hungary and Poland', in OECD (eds), Reforming Public Pensions. Paris: OECD.

Streeck, W and Thelen, K. (eds) (2005) Beyond Continuity: Institutional Change in Advanced Political Economies, Cambridge: Cambridge University Press.

Thaler, R and Sunstein, C, (2007) The Nudge. Yale university Press.

Thelen, K. (1999) 'Historical Institutionalism in Comparative Politics', Annual Review of Political Science, 2, 369-404.

Thelen, K. (2004) How Institutions Evolve: The Political Economy of Skills in Germany, Britain, the United States, and Japan. Cambridge: Cambridge University Press.

Thelen, K. (2009) 'Institutional Change in Advanced Political Economies', British Journal of Industrial Relations, 47, 3.

Thelen, K. and Steinmo, S. (1992) 'Institutionalism in Comparative Politics' in S. Steinmo, K. Thelen, and F. Longstreth (eds) Structuring Politics: Historical Institutionalism in Comparative Analysis. Cambridge: Cambridge University Press.

Tsai, K. (2006), 'Adaptive Informal Institutions and Endogenous Institutional Change in China', World Politics, 59, 1: 116-41. 
Waylen, G. (2007a) ‘Women's Moblization and Gender Outcomes in Transitions to Democracy: the South African Case', Comparative Political Studies. May, 40. 5.

Waylen, G. (2007b) Engendering Transitions: Women's Moblization, Institutions and Gender Outcomes; Oxford: Oxford University Press.

Waylen, G. (2009) 'What Can Historical Institutionalism Offer to Feminist Political Science?', Politics and Gender, 5, 2.

Waylen, G. (2011) 'Building New Democracies'. Paper presented to the final conference of the Leverhulme Programme Gendered Ceremony and Ritual in Parliament, London.

Waylen, G. (2014), 'Informal Institutions, Institutional Change and Gender Equality', Political Research Quarterly, 67, 1: 212-223.

Weldon, L. (2002) 'Beyond Bodies: Institutional Sources of Representation for Women in Democratic Policymaking', Journal of Politics, 64, 4: 1153-1174.

Notes

\footnotetext{
'For a more extended discussion of these issues see Waylen (2014).

ii At the same time, new rules embodying a particular Marxist-Leninist model of women's emancipation were introduced after communist revolutions such as the 1917 Bolshevik revolution in Russia.

iii There is a literature about the impact of pension reform in some developing countries.
} 